\title{
ANALISIS TEKSTUR PHOTO LAMA MENGGUNAKAN FITUR TEKSTUR GRAY LEVEL CO-OCCURRENCE MATRIKS PADA PEWARNAAN CITRA OTOMATIS
}

\author{
${ }^{1}$ Muhammad Sipan, ${ }^{2}$ Rony kartika Pramuyanti. \\ Jurusan Teknik Elektro, Fakultas Teknik Universitas Semarang
}

\begin{abstract}
Abstrak - Pengolahan citra merupakan hal penting pada sebuah proses pengenalan, klasifikasi atau segmentasi atau proses lain. Satu hal yang dapat dilakukan adalah analisis fitur tekstur yang berhubungan dengan photo lama dalam hal ini photo grayscale. Objek penelitian dapat berupa photo (citra) lama dan menggunakan metode statistikal berbasis Gray Level Cooccurrence Matrix (GLCM) .

GLCM adalah salah satu metode yang digunakan untuk ekstraksi fitur tekstur, beberapa tekstur yang ada di analisis menggunakan $\mathrm{glcm}$ dengan membandingkan fitur tektur GLCM pada photo lama dengan photo aslinya

Proses pewarnaan yaitu memberikan visualisasi lebih pada sebuah objek, dapat berupa citra atau video monokrom dengan tujuan untuk memberikan detail dan kejelasan dari citra atau video yang diwarnai. Penelitian membahas citra grayscale untuk diwarnai, kemudian mencari nilai-nilai fitur tekstur GLCM. Besar kecilnya nilai fitur yang diperoleh dari perhitungan digunakan untuk mencari seberapa besar nilai error yang secara tidak langsung menunjukan seberapa besar kemiripan citra tersebut. Pengukuran keberhasilan besar kecilnya kemirirpan menggunakan metode Mean Square Error (MSE) dan Mean Absolute Error (MAE).
\end{abstract}

Kata Kunci: Tekstur, GLCM, MAE, MSE.

Abstract - Image processing is important in a process of introduction, classification or segmentation or other processes. One thing that can be done is an analysis of the texture features related to old photos in this case grayscale photos. The object of the research can be an old photo (image) and use a statistical method based on Gray Level Counseling Matrix (GLCM).

GLCM is one of the methods used for extracting texture features, some of which are analyzed using glcm by comparing the GLCM texture feature in the old photo with the original photo

The coloring process is to provide more visualization of an object, it can be a monochrome image or video with the aim of providing details and clarity of the colored image or video. The study discusses grayscale images to be colored, then searches for GLCM texture feature values. The size of the features obtained from the calculation is used to find out how much the error value indirectly shows how much the image is similar. The measurement of the success of the small scale using the method of Mean Square Error (MSE) and Mean Absolute Error (MAE).

Keyword: Texture, Glcm, MAE, MSE

\section{PENDAHULUAN}

Ekstraksi fitur merupakan satu hal pokok dalam pengolahan citra, karena dari hasil ekstraksi fituri dapat dihasilkan informasi penting berupa deskripsi dan interpretasi pada sebuah objek[1]. sebuah citra mempunyai ciri yang dapat berupa bentuk, batas dan tepi, transformasi, momentum dan tekstur. Tekstur dapat didefinisikan sebagai pengelompokan kesamaan pada sebuah citra atau dengan kata lain perulangan tekstur dasar yang disebut texel. Texel terdiri dari sejumlah piksel dengan kemungkinan penempatan periodek, semi periodik maupun acak[1]. Tekstur yang terbentuk secara alami biasanya bersifat acak dan tekstur buatan memiiki pola yang periodik atau berulang.

Pada penelitian ini objek berupa citra lama (grayscale) pemandangan alam dan binatang yang akan di warnai, sebelumnya ditentukan fitur teksturnya kemudian di cari fitur tekstur dengan menggunakan GLCM untuk memperoleh matriks co-occurrernce Nilai-nilai matriks tersebut marupakan krakteristik dari tekstur citra yang kita cari.

\subsection{Analisis tekstur}

Analisis tekstur digunakan untuk berbagai aplikasi untuk memecahkan masalah dan mecapai tujuan tertentu seperti untuk keperluan identifikasi, [2][3] klasifikasi [4][5], analisis citra medis[6], dan aplikasi yang lainya.

Beberapa pendekatan yag biasa digunakan untuk analisis tekstur, menurut Bharati[3] adalah metode statistikal, metode struktural, metode berbasis model, metode berbasis transformasi. Salah satu metode statistikal adalah Gray level cooccurance matriks (GLCM), yang digunakan pada penelitian ekstraksi fitur pada percobaan penelitian ini.

\subsection{GLCM ( Gray Scale Co-Occurrence Matriks.}

GLCM yang jelaskan oleh Haralick [6] merupakan suatu metode statistikal untuk ekstraksi fitur tekstur dan termasuk yang paling banyak digunakan dalam teknik analisis tekstur [5]. kookuransi dapat di sebut sebagai kebersamaan, yaitu sebuah kejadian di mana satu level nilai keabuan sebuah piksel bertetangga dengan satu level nilai keabuan piksel yang lain. Misalkan L di artikan sebagai jarak atara dua piksel yang bertetangga. $\Theta$ merupakan sudut antar piksel dalam satuan derajat. dan $\mathrm{N}$ adalah jumlah level intensitas piksel pada sebuah citra. Maka GLCM adalah matriks bujur sangkar $P[i, j]$ yang memiliki dimensi $\mathrm{N}^{2}$, setiap elemen $[\mathrm{i}, \mathrm{j}]$ menyatakan sebagai peluang kejadian sebuah piksel berinstensitas i bertetangga dengan piksel intensitas $\mathrm{j}$ dan kedua piksel di pisahkan jarak sejauh $\mathrm{L}$ dan sudut $\theta$. Sudut $\theta$ memiliki empat arah sudut dengan interval $45^{\circ}$, dimulai dari $0^{\circ}, 45^{\circ}, 90^{\circ}$ dan $135^{\circ}$. ditunjukan pada gambar 3 .

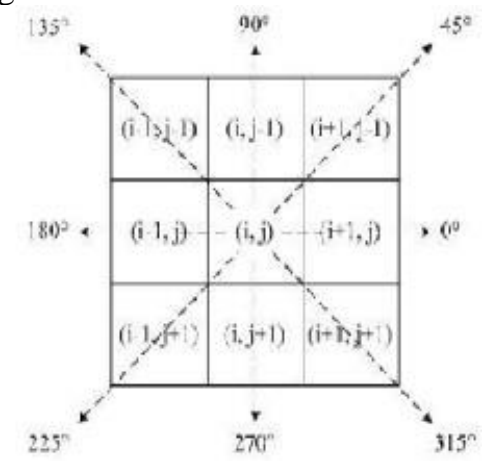

Gambar 1. Arah Ketetanggaan antara Dua Piksel. 
Dimisalkan ofset [l $\left.\begin{array}{ll}0 & 1\end{array}\right]$ ini berarti satu piksel ke sebelah kanan, jika dinyatakan dalam sudut adalah $0^{\circ}$ dengan $\mathrm{L}=1$.

Dari nilai co-occurance matriks dihasilkan berbagai ciri tekstur yang merupakan representasi citra. Ciri-ciri tersebut antara lain :

\section{Kontras}

Kontras merupakan ukuran keberadaan variasi aras keabuan piksel citra.

Kontras $=\sum_{i}^{L} \sum_{j}^{L}|i-j|^{2} \operatorname{GLCM}(i, j)$

2. ASM.

ASM menyatakan nilai homogenity suatu citra.

$$
A S M=\sum_{i=1}^{L} \sum_{j=1}^{L}(\operatorname{GLCM}(i, j))^{2}
$$

\section{IDM}

IDM digunakan untuk mnegukur homogenitas

$$
I D M=\sum_{i=1}^{L} \sum_{j=1}^{L} \frac{(G L C M(i, j))^{2}}{1+(i-j)^{2}}
$$

\section{Entropi}

Entropi merupakan ukuran ketidakteraturan aras keabuan pada citra.

Entropi $=--\sum_{i=1}^{L} \sum_{j=1}^{L}(G L C M(i, j)) \log (\operatorname{GLCM}(i, j))$

\section{Korelasi}

Korelasi menyatakan ukuran ketergantungan linear antara nilai aras pada citra.

Korelasi $=\sum_{i=1}^{L} \sum_{j=1}^{L} \frac{\left(i-\mu i^{\prime}\right)\left(j-\mu j^{\prime}\right)(\operatorname{GLCM}(i, j))}{\sigma_{i} \sigma_{j}}$

\section{METODE PENELITIAN}

Pada peneltian ini ada beberapa tahap yang dilakukan untuk memperoleh hasil ekstrasi ciri berupa matriks co-ocurance seperti pada gambar 1. Citra masukan berupa citra pemandangan alam yang di ambil dengan kamera digital dalam bentuk grayscale dan kemudian di akuisisi menjadi gambar yang berformat file jpg. Dari citra yang di gunakan di warnai secara otomatis. Hasil dari pewarnaan citra tersebut di cari fitur teksturnya dari masing-masing citra. Fitur tekstur yang digunakan ada lima yaitu, fitur kontras, ASM, IDM, entropi dan korelasi. Dari kelima fitur tersebut yang dperoleh di bandingkan dengan fitur tekstur citra aslinya kemudian dicari seberapa besar nilai Mean absolute error dan Mean Square errornya. Besar kecil nya nilai MAE dan MSE digunakan sebagai acuan untuk menilai seberapa besar kemiripan citra lama dengan citra aslinya. keabuan, kemudian ekstraksi ciri tekstur dilaksanakan berdasarkan matriks co-occuransi yang dapat dilihat pada gambar 2.

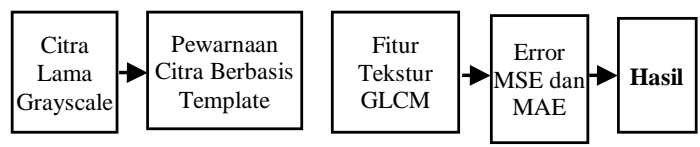

Gambar 2. Metode Penelitian

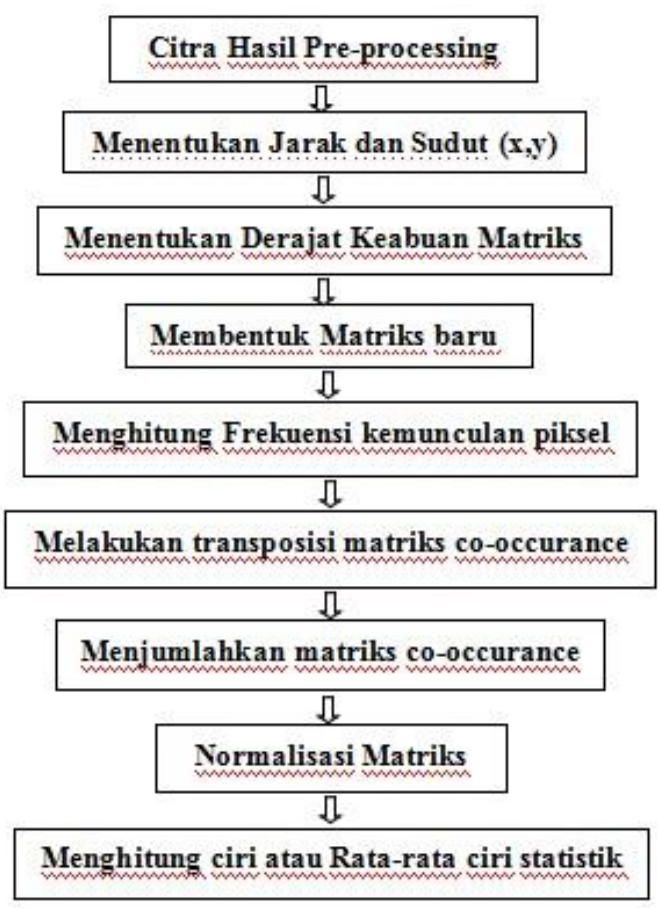

Gambar 3. Alur Menentukan GLCM

Dari hasil GLCM diperoleh ekstraksi beberapa ciri yang menjadi representasi citra. Penentuan jarak, sudut, dan gray level adalah parameter penting dalam mendefinisikan GLCM[11]. Penentuan Gray level dan sudut dilakukukan beberapa percobaa yang sama. Hui Wang [2] menggunakan $\mathrm{L}=4$, sedangkan Pramunendar [4] menggunakan $\mathrm{L}=3$. Penelitian ini menggunakan $\mathrm{L}=1$, dengan pemikiran komputasi yang lebih sederhana. Jarak yang di pilih sudah dapat menentukan fitur yang dibutuhkan.

\section{HASIL DAN PEMBAHASAN}

Penelitian ini menggunakan dua citra lama (grayscale) ditunjukkan pada Gambar 3. bagian kiri, yang di warnai terlebih dahulu baru di cari fitur-fitur teksturnya.

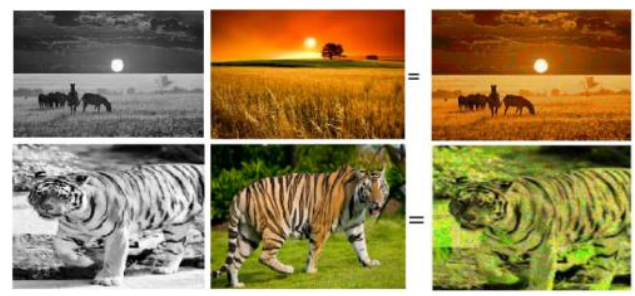

Gambar 4. Hasil Pewarnaan Citra

Citra pertama berupa citra pemandangan sunset terdiri beberapa tekstur yang terlihat secara kasat mata yaitu tektur awan, matahari, padang rumput dan tekstur hewan, sedangkan citra kedua yaitu berupa harimau dengan background rerumputan dan rimbunan pohon, dari citra ini terlihat beberapa tekstur yaitu tekstur harimau, rumput dan rimbunan pepohonan. Gambar 4. Menunjukan ( bagian kanan) hasil dari pewarnaan otomatis, dari kedua citra hasil penulis mencari fitur-fitur 
tekstur yang akan di bandingkan dengan citra aslinya. Hasil perbandingan nilai fitur tekstur tersebut.

Tabel 1. Hasil Perhitungan Nilai Error.

\begin{tabular}{|c|c|c|c|}
\hline \multirow{2}{\text{NAMA}}{$\begin{array}{c}\text { CITRA } \\
\text { TITUR }\end{array}$} & $\begin{array}{c}\text { TEKST } \\
\text { UR }\end{array}$ & MAE & MSE \\
\hline \multirow{4}{*}{$\begin{array}{c}\text { Citra } \\
\text { Sunset }\end{array}$} & ASM & 0,022039793 & $1,21438 \mathrm{E}-06$ \\
\cline { 2 - 4 } & IDM & 0,08725025 & $1,90315 \mathrm{E}-05$ \\
\cline { 2 - 4 } & Kontras & 9,02725 & 2,037281064 \\
\cline { 2 - 4 } & Korelasi & 0,0032762 & $2,68337 \mathrm{E}-08$ \\
\cline { 2 - 4 } & Entropi & 0,155 & $6,00625 \mathrm{E}-05$ \\
\hline \multirow{4}{*}{$\begin{array}{c}\text { Citra } \\
\text { Binatang }\end{array}$} & ASM & 0,019554438 & $9,5594 \mathrm{E}-07$ \\
\cline { 2 - 4 } & Kontras & 2,14315 & 1,148272981 \\
\cline { 2 - 4 } & Korelasi & 0,001877815 & $8,81547 \mathrm{E}-09$ \\
\cline { 2 - 4 } & Entropi & 0,07 & 0,00001225 \\
\hline
\end{tabular}

Tabel 1. Menunjukan hasil akhir dari nilai mean absolute error dan mean square error dari kelima fitur tekstur yang di gunakan.

\section{KESIMPULAN}

\subsection{Kesimpulan}

Penelitian ini dilakukan dengan melakukan beberapa uji coba yang menghasilkan sebuah nilai error, dari nilai error tersebut kita dapat ambil sebuah kesimpulan bahwa nilai error dari perhiungan MAE dan MSE didapatkan Nilai kurang dari 5\% ( Tabel 5.13). dari kelima fitur GLCM yang digunakan. Dari nilai error ini secara tidak langsung menunjukkan seberapa besar keberhasilan dari pewarnaan yang telah dilakukan.

\subsection{Saran}

Dari hasil penelitian yang dilakukan dan kesimpulan yang didapat, saran yang dapat penulis berikan untuk peneliti selanjutnya yaitu fitur yang digunakan dapat menggunakan fitur lainseperti fitur bentuk, luasan atau fitur warna. Data yang digunakan dapat lebih variatif dalam hal ini dalam satu citra perbedaan intensitasnya semakin banyak.

\section{DAFTAR PUSTAKA}

[1]. Ambika Kalia1, Balwinder Singh, "Colorization of Grayscale Images: An Overview", ournal of Global Research in Computer Science, Volume 2, No. 8, August 2011

[2]. R. Venkata Rahmana Chary, D. Rajya Laksmi, K.V.N. Sunitha." Feature extraction methods for color image similarity". Institute of Technology, India, 2012.

[3]. Shiguang liu, Xhiang Zhang, "Automatic Grayscale image colorasion using histogram regression", School of computer science and technology, Tianjin University, china, 2012.
[4]. V. konusin, V. vezhnevets, "interactive image colorization and recoloring base on coupled map lattices". Moscow State University, Rusia.

[5]. Zhong Zhen, qquad Gui Yan, qquad Ma Lizhuang," An Automatic Image and Video Colorization Algorithm based on Pattern Continuity", Shanghai Jiao Tong University, 2012.

[6]. Ustin Sousa, Rasoul Kabirzadeh, Patrick Blaes, "Automatic Colorization of Grayscale Images", Department of Electrical Engineering, Stanford University, 2013. 